\title{
ESTUDO SOBRE MORFODINÂMICA PRAIAL NA REGIÃO DE PORTO SEGURO E ADJACÊNCIAS
}

\author{
AUTOR: GABRIELA NUNES REBOUÇAS LEAL \\ CO-AUTOR/ORIENTADOR: JULIANA PEREIRA DE QUADROS
}

Resumo: As praias arenosas são ambientes dinâmicos e sensíveis, influenciadas por processos oceanográficos, atmosféricos e continentais. O objetivo do estudo foi avaliar a morfodinâmica praial do trecho litorâneo entre as praias de Coroa Vermelha e Taípe, nos municípios de Santa Cruz Cabrália e Porto Seguro - Bahia, com intuito de caracterizar as praias por meio de perfis praias e características de onda. Para isso, foram selecionados 18 pontos para fazer os perfis mensais, também foram coletados dados de onda como: arrebentação, altura e período. Os resultados mostraram que os pontos com maiores médias de altura de onda foram os P18, P17 e P12 com cerca de 0,91, 0,88 e 0,75m, consequentemente, enquanto o P1 registrou a menor média com $0,15 \mathrm{~m}$. Já o período os valores médios variaram de $5,95 \mathrm{~s}$ no P4 e 14s no P6. Em relação aos perfis praias, os pontos de maiores variações topográficas foram: P9, P10, P12, P16, P17 e P18. Quase todos os pontos foram classificados como praias intermediárias, somente o P6 que foi dissipativo e P12 refletivo. Dos 18 pontos, 10 são praias abrigadas. Essa alta dinâmica das praias estudadas ficou perceptível nas variações do tipo de arrebentação. A altura de onda nos pontos foi pequena, não ultrapassando 1 metro, muito por conta da presença dos recifes e costões rochosos. O método se mostrou eficiente nessa caracterização inicial, sendo esse monitoramento importante para avaliar a dinâmica costeira dessas praias, entretanto, outros fatores devem ser considerados para uma avaliação mais robusta, como a composição sedimentar, que também faz parte dos projetos do grupo de pesquisa.

Palavras-chave: Zona Costeira, Geomorfologia, Costa do descobrimento. 